\title{
Deglaciation chronology of the Pandivere and Palivere ice-marginal zones in Estonia
}

\author{
Leili SAARSE, Atko HEINSALU and Siim VESKI
}

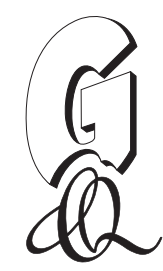

Saarse L., Heinsalu A. and Veski S. (2012) - Deglaciation chronology of the Pandivere and Palivere ice-marginal zones in Estonia. Geol. Quart., 56 (2): 353-362, doi: 10.7306/gq.1027

\begin{abstract}
Accelerator mass spectrometry (AMS) ${ }^{14} \mathrm{C}$ dates, pollen and plant macrofossil evidence and lithostratigraphic parameters obtained from four Late Glacial lake sediment records were used to study the deglaciation chronology of Estonia. AMS dates show that the northern part of the Saadjärv Drumlin Field was free of ice cover at approximately 14,300-14,200 cal yr BP. These ages fit well with the ice retreat estimations (14,700-14,500 cal yr BP) of the Otepää ice-marginal zone in the south and the deglaciation of the Pandivere Upland in the north $\left(13,800 \mathrm{cal}\right.$ yr BP). Glaciolacustrine sediments of the Haljala and Udriku basins were deposited in proglacial lake $\mathrm{A}_{1}$, a northeastern bay of the Baltic Ice Lake that already existed $c a .13,800 \mathrm{cal} \mathrm{yr} \mathrm{BP.} \mathrm{The} \mathrm{Palivere} \mathrm{ice-marginal} \mathrm{zone,} \mathrm{and} \mathrm{proglacial} \mathrm{lake} \mathrm{A}_{2}$ associated with it, was formed ca. 500 years later, at approximately 13,200 cal yr BP. New evidence indicates that ice readvance during the Palivere stade terminated during the Allerød chronozone.
\end{abstract}

Leili Saarse, Atko Heinsalu and Siim Veski, Institute of Geology at Tallinn University of Technology, Ehitajate tee 5, 19086 Tallinn, Estonia; e-mails: saarse@gi.ee, heinsalu@gi.ee,veski@gi.ee(received: June 20,2011, accepted: March 29, 2012; first published online: June 12, 2012).

Key words: deglaciation, Late Glacial, proglacial lakes, AMS ${ }^{14} \mathrm{C}$ radiocarbon dates, Estonia.

\section{INTRODUCTION}

The deglaciation pattern of the Scandinavian Ice Sheet (SIS) is well-reconstructed in Estonia and a general picture of the different stadials and interstadials has been presented (e.g., Raukas et al., 1971; Kalm, 2011). The Haanja, Otepää, Sakala, Pandivere and Palivere ice-marginal zones have been differentiated (Fig. 1A) according to more or less prominent landform complexes that may indicate minor standstills and oscillations of the ice margin during the ice retreat of the SIS. In previous Late Glacial stratigraphic studies of Estonia, chronostratigraphy was mostly based on palynological records (Pirrus, 1969; Pirrus and Rõuk, 1979; Pirrus and Raukas, 1996) and correlation with the Fennoscandian chronostratigraphical chart (Mangerud et al., 1974). However, the chronology of deglaciation is still debated, as different dating methods, including OSL, cosmogenic ${ }^{10} \mathrm{Be}$ dating and varvochronology have produced ages with large uncertainties (Raukas, 2004, 2009; Kalm, 2006). For example, the OSL dates from glaciofluvial deposits (Raukas and Stankowski, 2005) and ${ }^{10} \mathrm{Be}$ dates from erratic boulders have given ages that differ by thousands of years (Rinterknecht et al., 2006).
Therefore, tracking the precise timing of the SIS margin retreat in Estonia faces many challenges. The scarcity of organic material in the Late Glacial sediments limits the applicability of the conventional radiocarbon method to establishing reliable ice recession chronologies. The implementation of the AMS ${ }^{14} \mathrm{C}$ method, which significantly reduces the quantity of carbon required for obtaining radiocarbon dates, opened up new possibilities for dating terrestrial macrofossils preserved in minerogenic Late Glacial sediments. During the last decade, this method was widely used in the Baltic region for constraining Late Glacial chronostratigraphy and ice recession chronology (Stančikaitė et al., 2002, 2004, 2008; Lõugas et al., 2002; Heikkilä et al., 2009; Saarse et al., 2009; Amon and Saarse, 2010; Kihno et al., 2011; Amon et al., 2012). However, it should be taken into consideration that radiocarbon ages obtained from the basal sediment layers that are preserved in lake depressions do not directly date the deglaciation but merely indicate the minimum time when the area became ice-free. There can be a time lag between the ice margin retreat and the start of sedimentation in basins, as well as in the onset of vegetation colonisation and organic production. Pioneer vegetation, however, may be quickly established on mineral substrates that are exposed after ice-margin recession. The primary plant succession on recently 

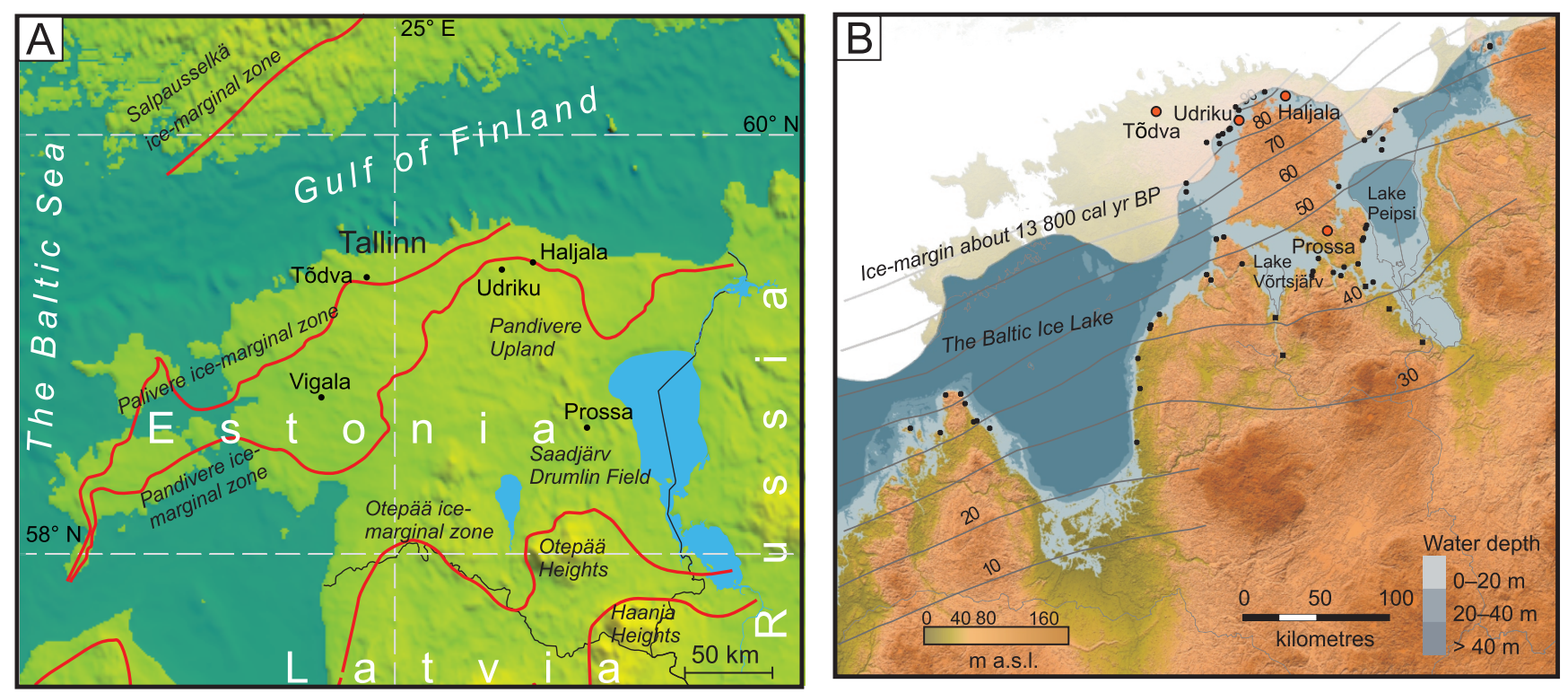

Fig. 1A - location of sites studied with indication of the ice-marginal zones discussed in the text, the Sakala zone is poorly defined and not indicated; $B$ - ice margin position during the Pandivere stage with indicating the distribution of the $A_{1}$ proglacial lake about 13800 cal yr BP, reconstruction by Rosentau (2009) with authors' improvements

deglaciated forelands in the high arctic has shown that vegetation colonises newly exposed surfaces within the first decade after ice retreat (Jones and Henry, 2003). Thus, dating terrestrial plant macrofossils from the basal parts of Late Glacial lake sediments to establish an ice recession chronology may add independent data to our knowledge.

The aim of the current study was to highlight the ice recession pattern in North Estonia on the basis of newly obtained absolute ages from four Late Glacial sites: Prossa, Udriku, Haljala and Tõdva. The southernmost site, the Lake Prossa sequence, is located between the Otepää and Pandivere ice-marginal zones. The Udriku site is situated within the Pandivere ice-marginal zone, the Haljala site on the northern slope of the Pandivere Upland and the Tõdva site beyond the Palivere ice-marginal zone (Fig. 1A). Prior to our studies, only one AMS radiocarbon date was available from the Late Glacial basal deposits of the Saadjärv Drumlin Field (Sohar and Meidla, 2009), and none were available from the Late Glacial deposits related to the Palivere zone. All these sites have been studied, and the original material has been published in different papers (Saarse et al., 2009; Amon and Saarse, 2010; Kihno et al., 2011; Saarse, 2011). In the current paper, we synthesise the results of these studies and present an overall ice recession chronology for the three main ice-marginal zones in Estonia.

\section{MATERIAL AND METHODS}

Pollen, macrofossils, grain size, loss-on-ignition (LOI), magnetic susceptibility (MS) and $\mathrm{AMS}{ }^{14} \mathrm{C}$ dates were applied in overlapping cores extracted with a one-m-long Russian peat sampler. The cores were described and photographed in the field, packed into plastic semitubes, wrapped in polyethylene film, transported to the laboratory and stored in a cool room. $1 \mathrm{~cm}$ thick subsamples for LOI analyses were taken continuously, and $1 \mathrm{~cm}$ thick samples were taken for grain-size distri- bution at $2-10 \mathrm{~cm}$ intervals. Bulk samples for LOI were weighed, dried at $105^{\circ} \mathrm{C}$ overnight, and combusted at 525 and $900^{\circ} \mathrm{C}$ to calculate moisture, organic matter (OM), carbonate and minerogenic compounds (Fig. 2). The grain-size distribution was analysed using an $L A-950 \mathrm{~V} 2$ laser scattering particle size distribution analyser which measures grain size within the range of $0.01 \mu \mathrm{m}$ to $3 \mathrm{~mm}$ and distinguishes 89 fractions. To avoid grain flocculation, the samples were pre-treated with a $1 \%$ solution of $\mathrm{Na}_{4} \mathrm{P}_{2} \mathrm{O}_{7} \times 10\left(\mathrm{H}_{2} \mathrm{O}\right)$. MS was measured with a Bartington Instruments MS2E high-resolution surface scanning sensor along carefully cleaned flat surfaces of fresh sediments, which were covered by a thin plastic film, at a resolution of 1-2 cm. Subsamples for the pollen analyses $\left(1-2 \mathrm{~cm}^{3}\right)$ were prepared according to Berglund and Ralska-Jasiewiczowa (1986). The minerogenic samples were treated with concentrated HF. Lycopodium tablets were added to calculate the pollen concentration and accumulation rates (Stockmarr, 1971). Macrofossils were extracted by soaking the $5 \mathrm{~cm}$ thick samples $\left(160-300 \mathrm{~cm}^{3}\right.$, mostly $\left.210-220 \mathrm{~cm}^{3}\right)$ in the water and $\mathrm{Na}_{4} \mathrm{P}_{2} \mathrm{O}_{7}$ solution and were sieved through a $0.25 \mathrm{~mm}$ mesh. The plant remains were identified under a binocular microscope. The LOI diagrams were plotted with the TILIA and TGView programs (Grimm, 2007). The AMS ${ }^{14} \mathrm{C}$ dates from mainly terrestrial plant remains were obtained at the Poznan and Uppsala radiocarbon laboratories (Table 1) and were calibrated and given in calendar years using the calibration dataset from Reimer et al. (2004) and the CALIB 5.0.1 software (Stuiver et al., 2005).

\section{RESULTS BY SITE}

Lake Prossa $\left(58^{\circ} 38^{\prime} 57^{\prime \prime} \mathrm{N}, 26^{\circ} 34^{\prime} 40^{\prime \prime} \mathrm{E}\right)$ is a mesotrophic lake that is 24.2 ha in area and is located in the northwestern part of the Saadjärv Drumlin Field at $61 \mathrm{~m}$ above sea level (a.s.l.) (Fig. 1). The lake surroundings can be described as a landscape with large NW-SE-orientated drumlins. The lake it- 
self is shallow, with peaty shores covered by a floating mat. The basin morphology resembles that of a reversed drumlin. The cross-sections along the Prossa basin show a rather even mineral bottom topography (Saarse, 1994) filled with till, varved clay, sandy and clayey silt with plant detritus, gyttja and calcareous gyttja (Fig. 2A), forming a sedimentary sequence of glacial, glaciolacustrine and lacustrine beds.

The lowermost part of the core studied $(760-745 \mathrm{~cm})$ consists of massive sandy silt with a relatively high abundance of sand fraction that resembles till deposits. This unit is covered by distinctly varved clay (745-708 cm; Fig. 2A), of which 29 annual varves have been encountered. The varved clay unit is overlain by an $8 \mathrm{~cm}$ thick massive clayey silt $(708-700 \mathrm{~cm})$ and laminated calcareous clayey silt $(700-650 \mathrm{~cm})$, which includes irregular, obviously pyritised black stripes (Fig. 3). The OM content in clayey sediments is scant, but the carbonate content reaches 24\% (Fig. 2A). Between 650 and $630 \mathrm{~cm}$ the sand fraction increases (Fig. 4A). The pollen assemblages and the findings of Dryas octopela leaves and Betula nana seeds in the above-mentioned sediments suggest a sparsely vegetated subarctic tundra landscape (Kihno et al., 2011). The lithostratigraphic boundary between the sandy silt and silt at $630 \mathrm{~cm}$ is rich in plant remains, and it marks the isolation of the Prossa basin from the large proglacial lake at the beginning of the Allerød (Kihno et al., 2011). Silt and clayey silt accumulated in the isolated lake. In the sediments of Younger Dryas age, moss-rich layers are apparent, including Drepanocladus, indicating a cold, oligotrophic clear-water environment. A remarkable change in sediment composition is found at the core depth of $550 \mathrm{~cm}$. This changes correlates with the Late Glacial/Holocene boundary and marks a hiatus in the sediment core caused by a lowering of the water level (Kihno et al., 2011).

Udriku Suurjärv is a small (23.7 ha) and shallow (6.8 m) lake $\left(59^{\circ} 22^{\prime} 17^{\prime \prime} \mathrm{N}, 25^{\circ} 55^{\prime} 50^{\prime \prime} \mathrm{E}\right)$ on the Pandivere Upland between esker ridges at an altitude of $95.1 \mathrm{~m}$ a.s.l. (Fig. 1). The hummocky and rolling landscape on the lake catchment, with a height reaching $115 \mathrm{~m}$ a.s.1., is mainly composed of sand and gravel, while the surrounding lowland is covered by peat deposits. The peaty lake shores are strongly abraded, and pine trunks and peat cover the narrow NW littoral zone. The lake basin is filled with laminated clayey silt, silt with plant remains and silty gyttja, representing glaciolacustrine and lacustrine palaeoenvironments.

The bottommost laminated clayey silt $(828-800 \mathrm{~cm})$ resembles varved clay. The OM and carbonate content is low (Fig. 2B), and the clay fraction is relatively high, reaching $27 \%$ (Fig. 4B). This portion of the sediment is poor in macroremains, containing mostly Salix polaris leaves (Amon and Saarse, 2010). A sharp increase in the sand fraction from 16 to $31 \%$ at $800 \mathrm{~cm}$ obviously corresponds to the isolation of the Udriku basin from the Baltic Ice Lake at approximately 13,600 cal yr BP (Amon and Saarse, 2010). In sandy silt and silt (800-755 cm), the OM content increases, as do macroremains, dominated by Dryas octopetala and Ranunculus sect Batrachium and Nitella oospores remains suggesting increased summer temperatures during the late Allerød (Amon and Saarse, 2010). In the overlying silt, at a core depth between 755 and $678 \mathrm{~cm}$, the sediment contains dis- persed OM and sparse plant remains. Due to the Younger Dryas cooling, the abundance and diversity of macrofossils declined. The pollen evidence shows treeless tundra conditions throughout the Late Glacial part of the sediment sequence. The accumulation rate of tree pollen was fairly low, and various herbs dominate the local flora. At the Late Glacial/Holocene boundary between 680 and $670 \mathrm{~cm}$, the sediment rapidly changes into organic-rich gyttja, and fossil evidence shows developing forests.

Palaeolake Haljala $\left(59^{\circ} 25^{\prime} 27^{\prime \prime} \mathrm{N}, 26^{\circ} 17^{\prime} 42^{\prime \prime} \mathrm{E}\right)$ is located on the northern slope of the Pandivere Upland at an elevation of 67-68 $\mathrm{m}$ a.s.1. (Fig. 1). The ancient lake was approximately $4.6 \mathrm{~km}$ long and $200 \mathrm{~m}$ wide and was dammed by a spit. During the $\mathrm{A}_{1}$ phase of the Baltic Ice Lake (BIL), Haljala served as an ancient lagoon (Saarse et al., 2009). The basin is filled with glacial, glaciolacustrine and lacustrine sediments. This former lake has been reclaimed and transformed into grassland.

The LOI results of the Late Glacial sediments are quite similar to those of Udriku, being poor in $\mathrm{OM}$ and carbonates (Fig. 2C); however, they differ in grain-size composition, containing more clay and less sand fraction (Fig. 4C). The sediments between 500 and $220 \mathrm{~cm}$ were deposited in a proglacial environment, the uppermost part in the isolated lake, which was paludified in the early Holocene. In the Late Glacial sediment, Dryas octopetala and Salix sp. leaves, Ranunculus sect Batrachium seeds, Betula nana, Helianthemum and other plant macroremains and pollen typical the Late Glacial environment have been identified, but not wood remains, indicating treeless tundra vegetation (Saarse et al., 2009). The pollen record from the Late Glacial portion of the sediment shows a high frequency of Pinus pollen, which was obviously transported over long distances. However, the Betula humilis seed in the sediments dated to 13,800 cal yr BP suggests the possibility that individual birch trees could have colonised the lake catchment (Saarse et al., 2009).

Palaeolake Tõdva $\left(59^{\circ} 16^{\prime} 36^{\prime \prime} \mathrm{N}, 26^{\circ} 43^{\prime} 55^{\prime \prime} \mathrm{E}\right)$ belongs to the Palivere ice-marginal zone. This lake is located $12 \mathrm{~km}$ south of Tallinn at an altitude of 37-37.5 m a.s.1., covering an area of 1130 ha. The basin was flooded by waters of the BIL and the Yoldia Sea (Heinsalu and Veski, 2007), which left clayey silt and sand in its basal part (Fig. 2D). Later, these sediments were covered by lacustrine lime and peat. The basin outline is winding, and the bottom topography is uneven, with several deeper hollows where residual lakes persisted and lacustrine lime deposited up to the end of the Atlantic chronozone before filling and peat bog formation (Veber, 1969).

The lowermost sandy silt $(520-510 \mathrm{~cm})$ is overlain by bluish-grey massive clayey silt $(510-478 \mathrm{~cm})$ with low $\mathrm{OM}$ and carbonate content (Figs. 2D and 4D). The sandy silt between 478 and $447 \mathrm{~cm}$ has a rhythmic pattern (Fig. 3) and includes scattered mollusc shells followed upwards by lacustrine lime alternating with bluish silt, which gradually turns to lacustrine lime. The OM content is very low throughout the studied sequence, but the carbonate content increases in the topmost part of the sequence (Fig. 2D). The Tõdva basin isolated slowly between 11,600 and 11,400 cal yr BP. According to the pollen analyses (Veber, 1969) and AMS chronology (Table 1), the sedimentation of silt started at the end of the Allerød and terminated during the Preboreal. 

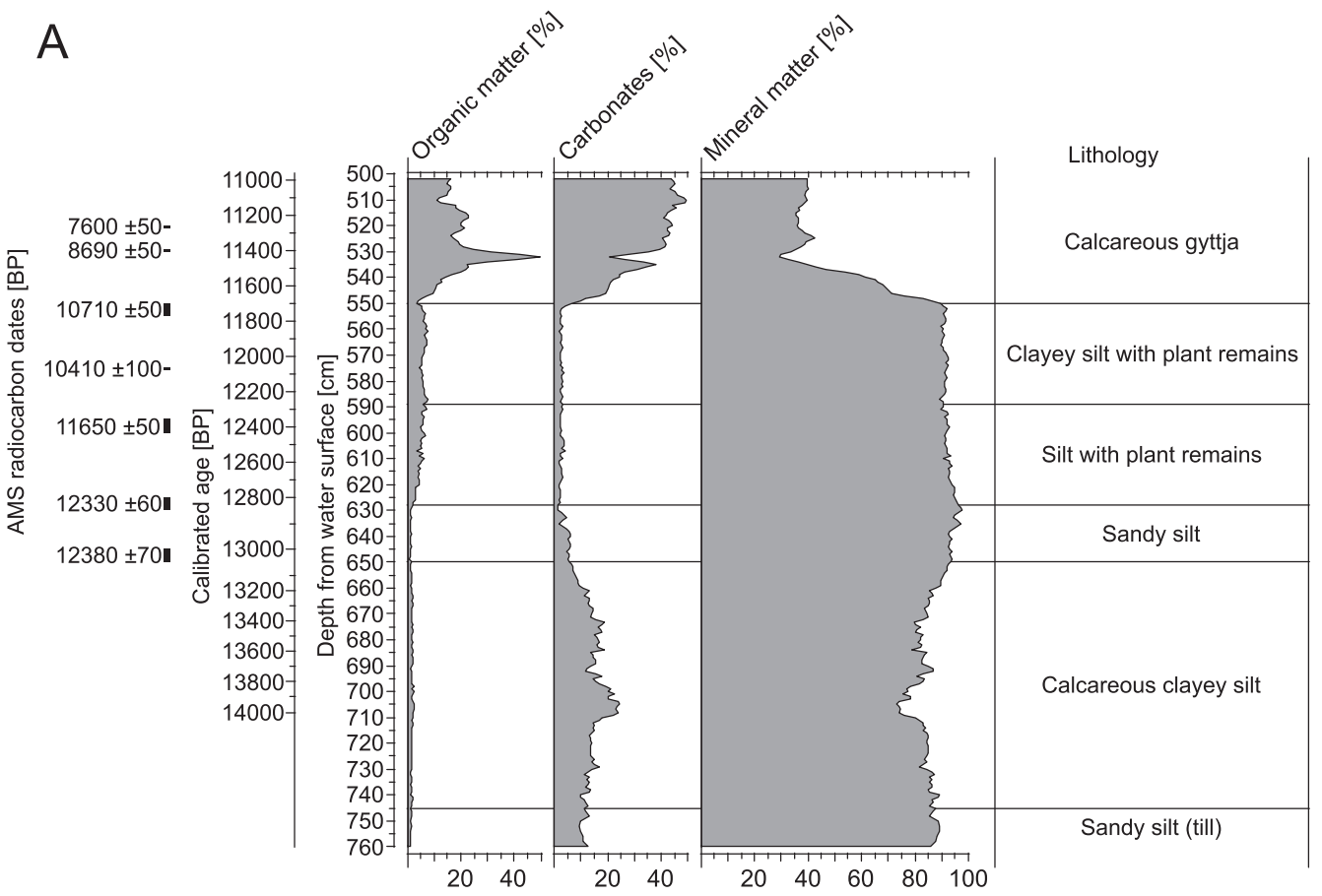

B
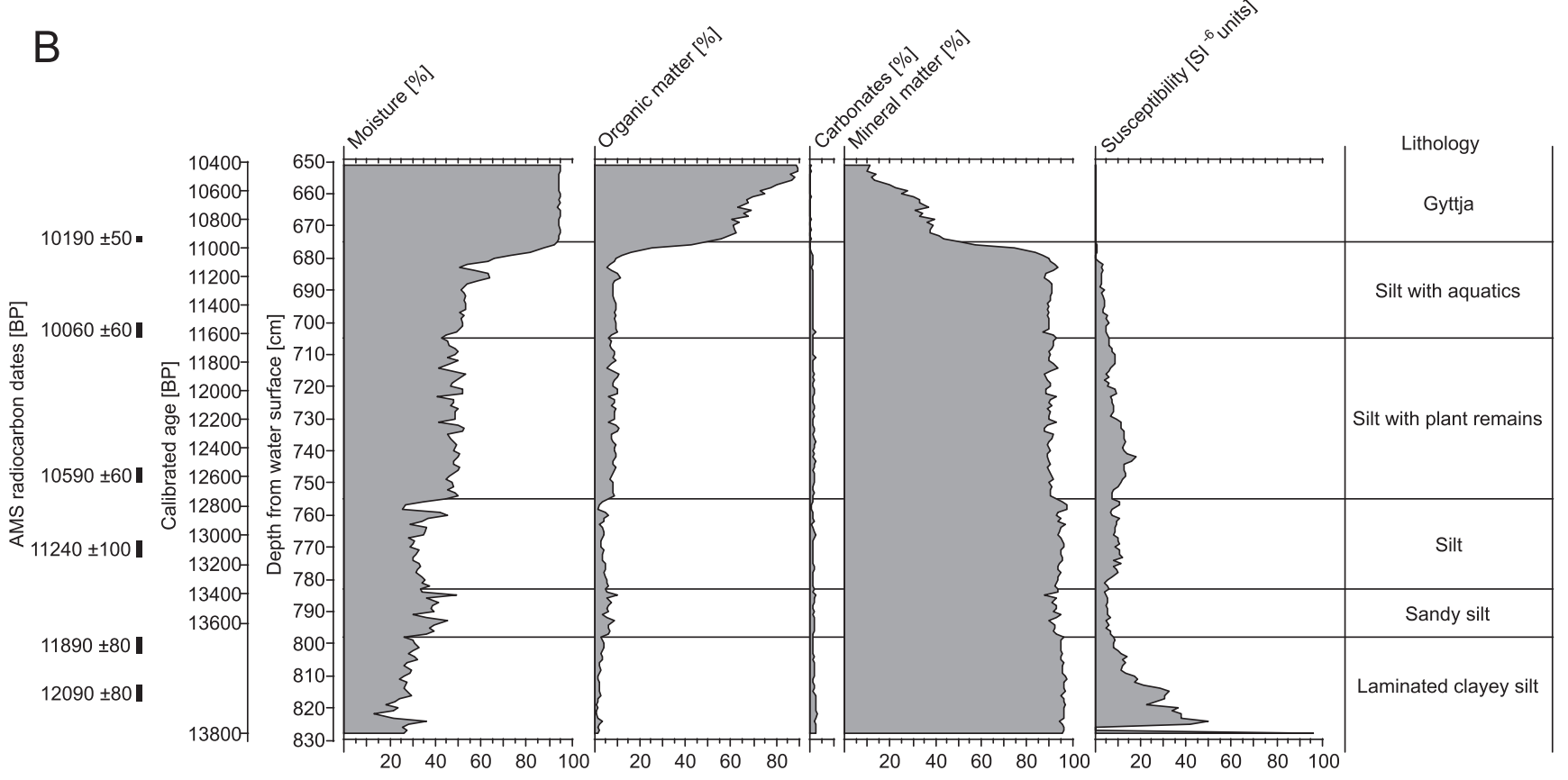

Fig. 2. Loss-on-ignition results from the Prossa (A), Udriku (B),

\section{CHRONOLOGY OF DEGLACIATION - DISCUSSION}

According to recent estimations, the Saadjärv Drumlin Field between the Otepää and Pandivere ice-marginal zones started to deglaciate at approximately $14,000-13,800$ cal yr BP (Rosentau et al., 2007). AMS dates (12,380 \pm 70 and $12,350 \pm 60{ }^{14} \mathrm{C} \mathrm{BP} ; 14,370$ and 14,245 cal yr BP, respectively) of the terrestrial plant macroremains of the Lake Prossa silt show that the varved clays below the silt had already been deposited by 14,300 cal yr BP (Figs. 2 and 5). These values are in good agreement with the age of the Otepää ice-marginal zone
(14,700-14,500 cal yr BP; Kalm, 2006), located ca. $50 \mathrm{~km}$ south of Lake Prossa, and they roughly correspond with the age of the Sakala zone, which is correlated with the Valdemarpils zone in Latvia and the Older Dryas chronozone (Zelčs and Markots, 2004).

The age of the Pandivere ice-marginal zone has been revised on the basis of the AMS ${ }^{14} \mathrm{C}$ dates from the Haljala and Udriku sites (Figs. 2 and 5). These sites are located close to the northern limit of the Pandivere ice-marginal zone (Fig. 1A) and were temporarily flooded by the waters of the BIL (Saarse et al., 2009). The AMS ${ }^{14} \mathrm{C}$ dates confirm that sedimentation in these basins started no later than 


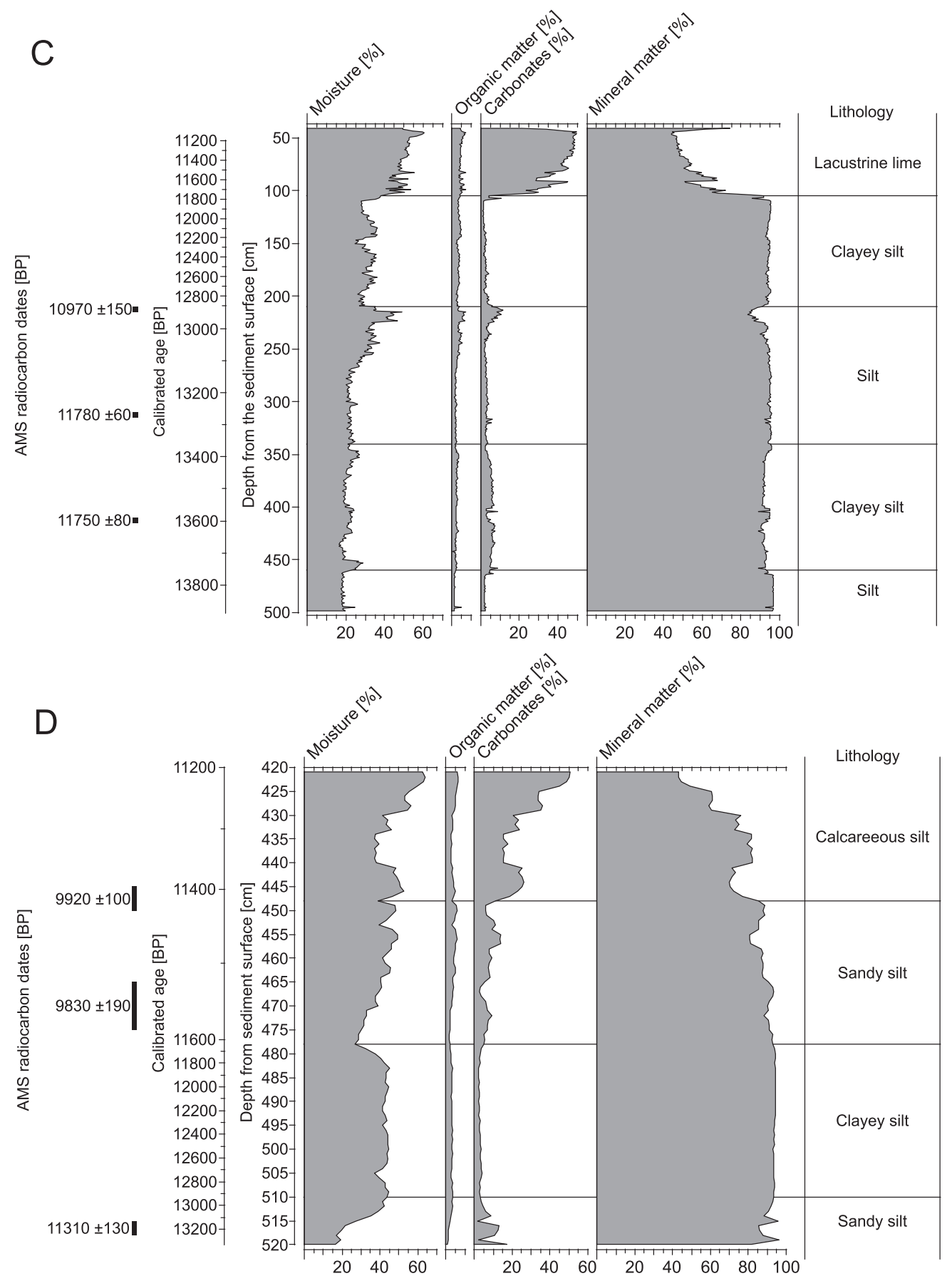

\section{Haljala (C) and Tõdva (D) deposits}

13,800 cal yr BP (Fig. 5; Saarse et al., 2009; Amon and Saarse, 2010), supporting the idea that the study areas were free of ice by that time. Our dates conform to varve counts in the Pärnu area, and they place the stagnation of the Pandivere zone within ca. 13,900-13,800 cal yr BP (Hang et al., 2011). These ages are 300-500 years older than those suggested earlier (Vassiljev et al., 2005; Saarse et al., 2007; Rosentau et al., 2009) based on data from the Karelian Isthmus (Wohlfarth et al. 1999; Saarnisto and Saarinen, 2001), as AMS dates from the Estonian sites were not available at that time. The ice recession could have occurred even earlier, as lacustrine sedi- mentation in front of the receding glacier may have been delayed by a few hundred years (Warner et al., 1991).

The age of the Palivere ice-marginal zone has been revised several times due to the application of different dating methods that did not produce reliable results (Raukas, 2009). Serebryanny and Raukas (1966) correlated the Palivere ice readvance with the Vimmerby advance in Sweden in contrast to Berglund (1979), who correlated the Palivere zone with the Levene Moraines in Central Sweden. The age of the Vimmerby advance was recently reappraised using the terrestrial cosmogenic nuclide method and was dated to $c a$. 


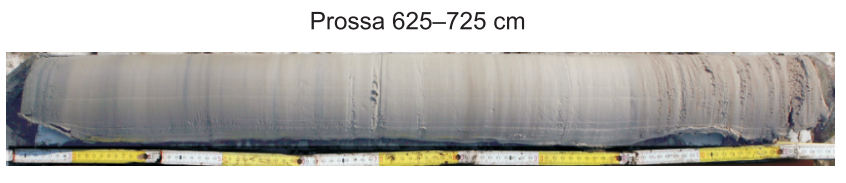

Udriku $724-824 \mathrm{~cm}$

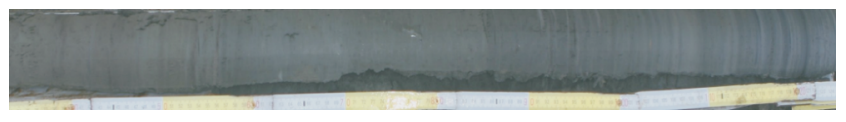

Haljala $153-253 \mathrm{~cm}$

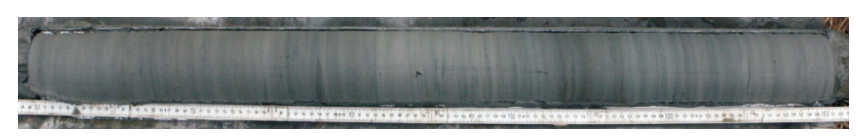

Tõdva $417-517 \mathrm{~cm}$

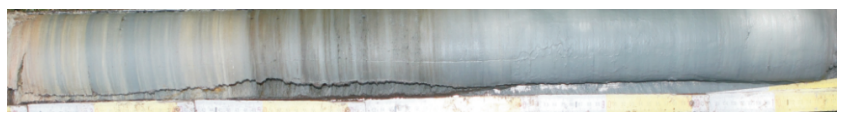

Fig. 3. Photo images of the sediment cores studied

In the Prossa sequence varved clays form the basal part with 29 annual varves. The Haljala sequence is entirely laminated. In the Udriku sequence only the basal $18 \mathrm{~cm}$ is laminated. The Tõdva sequence is clearly laminated between 450 and $470 \mathrm{~cm}$.
14,000 ${ }^{10} \mathrm{Be}$ yr (Johnsen et al., 2009; Johnsen, 2010). The ${ }^{10} \mathrm{Be}$ technique has also been applied in studies of the Palivere ice-marginal zone of Estonia. The age of 10 erratic boulders was found to range from 5200 to 15,200 years, with a mean of $13,600 \pm 1200{ }^{10} \mathrm{Be} y r$ (Rinterknecht et al., 2006). Such deviation could result from the variously eroded surfaces of boulders and/or because several of the sampled erratics lie at the contemporary sea level and were covered with waters of different stages of the Baltic Sea before they were exposed. The dating of glaciofluvial deposits by the OSL method did not produce good results either (Raukas and Stankowski, 2005). One reason could be that the sediments were not exposed properly to light during their formation or transportation (Johnsen, 2010). Finally, Raukas (2009) tentatively suggested that the Palivere ice-marginal belt was formed at approximately $11,500{ }^{14} \mathrm{C} \mathrm{yr}$ BP $(13,300$ cal yr BP) and that Estonia became free of ice cover in the second half of the Allerød (Pirrus and Raukas, 1996). Kalm (2011) and Kalm with co-authors (Kalm et al., 2011) suggested that the Palivere zone was formed later.

If the age of the Pandivere zone is $13,800 \mathrm{cal} \mathrm{yr} \mathrm{BP}$ and the ice retreat from the Pandivere to the Palivere zone took place within 476 varve years (Hang and Sandgren, 1996), the Palivere ice-marginal zone and the related BIL $\mathrm{A}_{2}$ proglacial lake could have been formed $c a$. 13,300-13,200 cal yr BP. The ${ }^{10} \mathrm{Be}$ age from the erratic boulder at Kallaste $(13 \mathrm{~km}$ west of Tallinn) showed a similar age - 13,440 \pm 1300 (Rinterknecht $e t$ al., 2006). The bottommost glaciolacustrine sediment from the

T a b 1 e 1

Radiocarbon dates from the studied sites

\begin{tabular}{|c|c|c|c|c|}
\hline Depth $[\mathrm{cm}]$ & AMS ${ }^{14} \mathrm{C}$ date & Lab. no & Calibrated age & Dated material \\
\hline \multicolumn{5}{|c|}{ Prossa } \\
\hline $550-555$ & $10,710 \pm 50$ & Poz-35466 & $12,825-12,735$ & Macros, unidentified \\
\hline 575 & $10,410+100$ & Poz-38459 & $12,580-12,105$ & Dryas leaves \\
\hline $595-600$ & $11,650 \pm 50$ & Poz-35467 & $13,575-13,420$ & Macros, unidentified \\
\hline $625-630$ & $12,330 \pm 60$ & Poz-35468 & $14,405-14,090$ & Macros, unidentified \\
\hline $645-650$ & $12,380 \pm 70$ & Poz-36169 & $14,580-14,165$ & Dryas leaves \\
\hline \multicolumn{5}{|c|}{ Udriku } \\
\hline $673-675$ & $10,190 \pm 50$ & Poz-31429 & $11,770-11,995$ & Leave fragments \\
\hline $705-700$ & $10,060+60$ & Poz-30769 & $11,750-11,405$ & Dryas leaves \\
\hline $745-750$ & $10,590 \pm 60$ & Poz-30429 & $12,770-12,410$ & Dryas leaves \\
\hline $768-773$ & $11,240 \pm 100$ & Poz-36168 & $13,235-13,055$ & Dryas leaves \\
\hline $798-803$ & $11,890 \pm 80$ & Poz-30430 & $13,835-13,665$ & Dryas leaves \\
\hline $813-818$ & $12,090 \pm 80$ & Poz-36201 & $14,025-13,845$ & Dryas leaves \\
\hline \multicolumn{5}{|c|}{ Haljala } \\
\hline $210-215$ & $10,970 \pm 150$ & Poz-22529 & $11,100-10,890$ & Macrofossils \\
\hline $310-315$ & $11,780 \pm 60$ & Poz-22530 & $13,570-13,740$ & Macrofossils \\
\hline $410-415$ & $11,750 \pm 80$ & Poz-22531 & $13,500-13,710$ & Macrofossils \\
\hline \multicolumn{5}{|c|}{ Tõdva } \\
\hline $445-450$ & $9920 \pm 100$ & Poz-39127 & $11,230-11,600$ & Dryas leaves \\
\hline $465-475$ & $9830 \pm 190$ & Poz-39129 & $10,830-11,700$ & Leaves \\
\hline $515-518$ & $11,310 \pm 130$ & Poz-39130 & $13,080-13,300$ & Dryas leaves \\
\hline
\end{tabular}



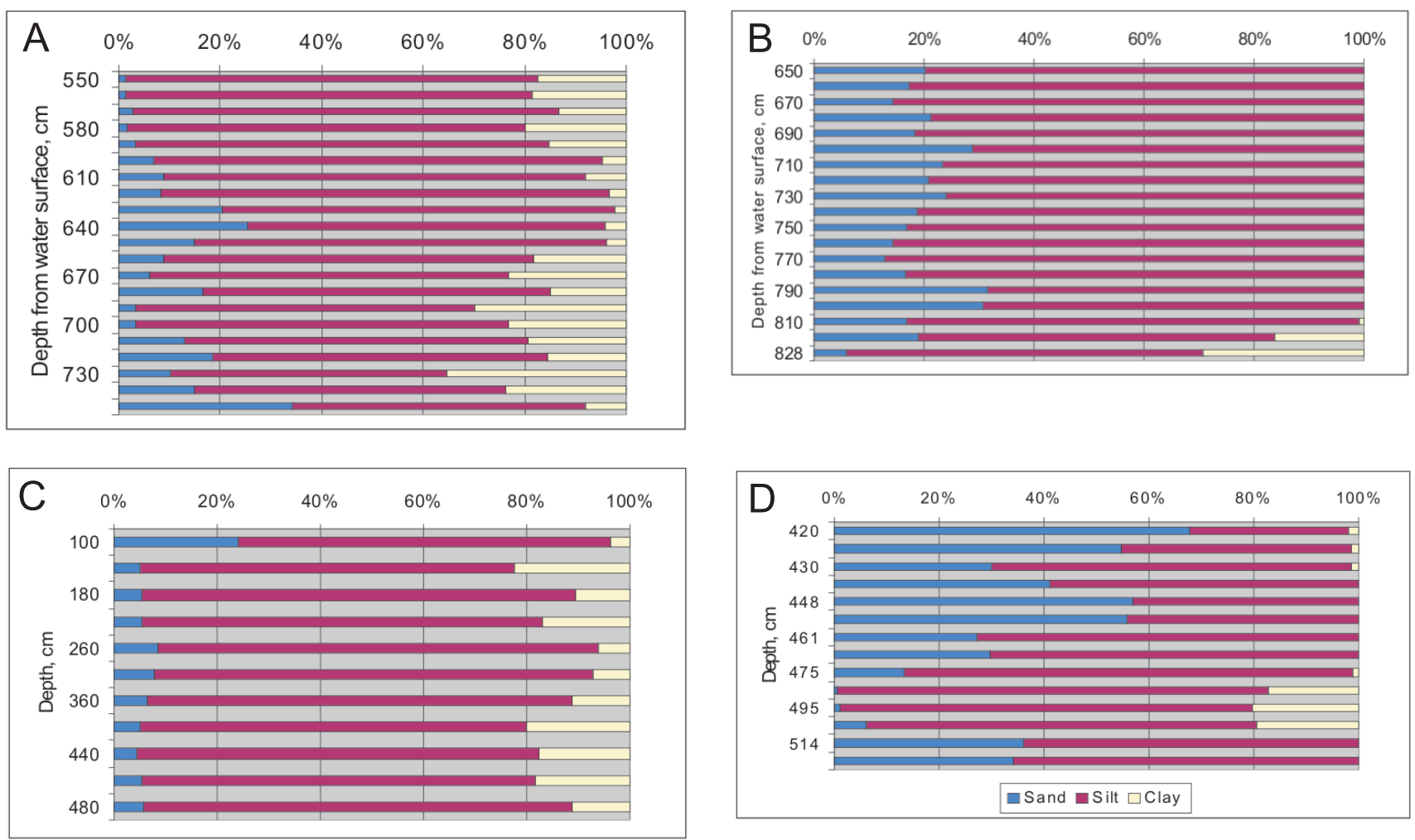

Fig. 4. Grain-size distribution of the Prossa (A), Udriku (B), Haljala (C) and Tõdva (D) deposits
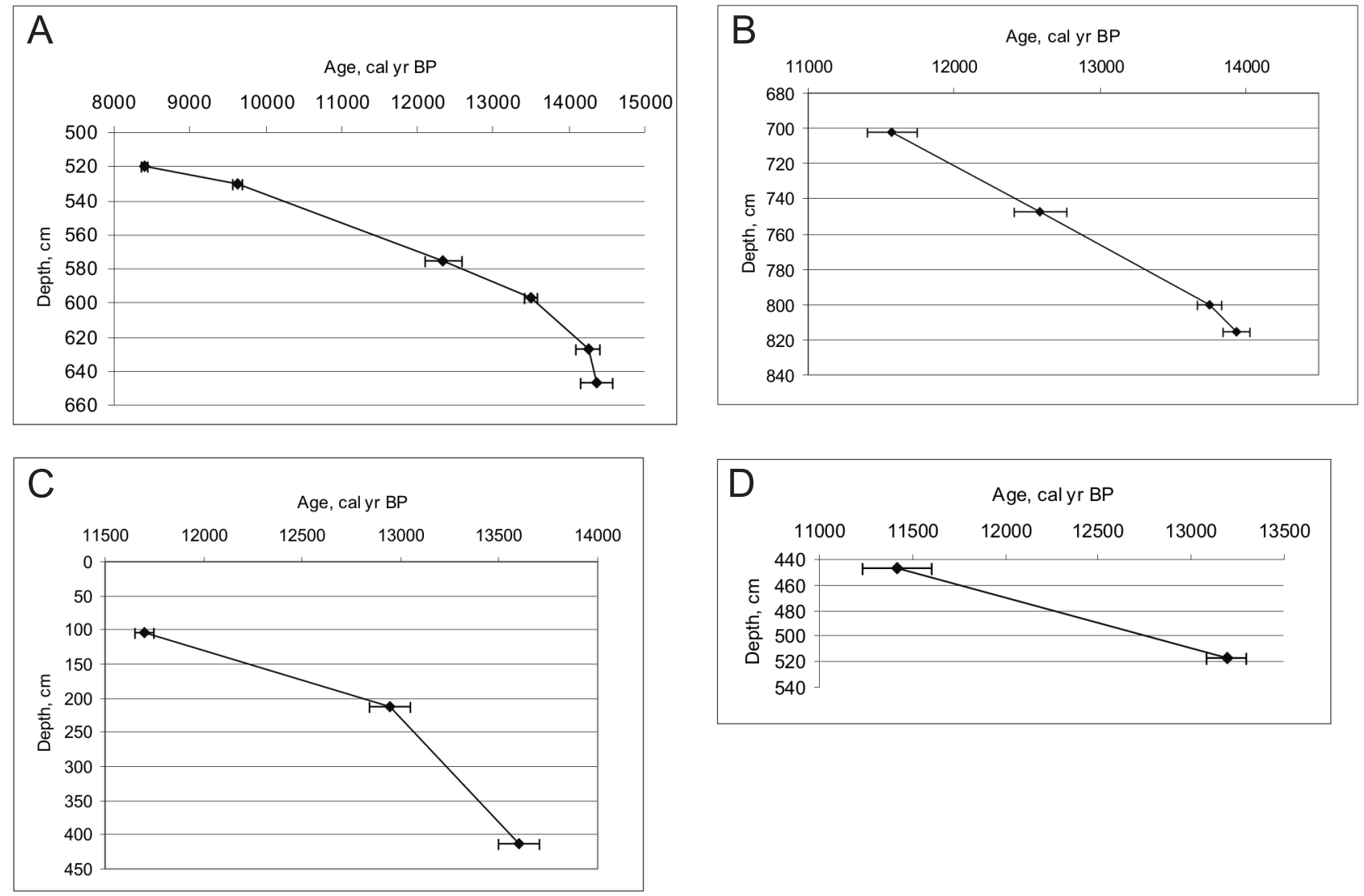

Fig. 5. Age-depth model from the Prossa (A), Udriku (B), Haljala (C) and Tõdva (D) deposits 
Tõdva sequence yielded a minimum age of $13,190 \pm 110 \mathrm{cal}$ yr BP (Poz-39130) for deglaciation. This time span differs slightly from that we suggested earlier (Vassiljev et al., 2005). The AMS date (Figs. 2 and 5) and the pollen assemblages show that the surrounding landscape of Tõdva was already free of ice during the Allerød chronozone. This evidence is in good accord with the latest results from Finland, according to which the ice margin reached the southern coast of Finland at approximately 13,000 cal yr BP (Lunkka et al., 2004) and remained at the Salpausselkä I Moraine position by $c a$. $12,500 \mathrm{cal}$ yr BP (Svendsen et al., 2004) or $12,500 \pm 700{ }^{10} \mathrm{Be}$ years (Rinterknecht et al., 2004). It is possible that the Palivere ice-marginal zone was formed at the same time as the Levene marginal zone in Sweden (13,400 cal yr BP; Lundqvist and Wohlfarth, 2001), as suggested by Berglund (1979) and Lundqvist (1992; cited after Lokrantz and Sohlenius, 2006).

\section{CONCLUSIONS}

1. Plant macrofossils, AMS ${ }^{14} \mathrm{C}$ dates and lithostratigraphical parameters were used to study the ice recession chronology and age of proglacial lakes in Estonia.

2. AMS ${ }^{14} \mathrm{C}$ dates from Lake Prossa, between the Otepää and Pandivere ice-marginal zones, indicate that the study site was free of ice at approximately 14,300 cal yr BP, and they support the age proposed for the Otepää zone $(14,700-4500$ cal yr BP).
3. The ice front had retreated to the northern slope of the Pandivere Upland by 13,800 cal yr BP, as confirmed by the AMS ${ }^{14} \mathrm{C}$ dates and cold-tolerant pollen and plant remains found in the glaciolacustrine sediments of the Udriku and Haljala sites.

4. Glaciolacustrine sediments of the Haljala and Udriku basins are deposited in proglacial lake $\mathrm{A}_{1}$, a northeastern bay of the BIL, confirming that proglacial lake $\mathrm{A}_{1}$ already existed at 13,800 cal yr BP.

5. The Palivere ice-marginal zone and proglacial lake $\mathrm{A}_{2}$ associated with it were formed later, $c a$. 13,300-13,200 cal yr BP, which is in good accord with the latest results from southern Finland and Sweden.

6. The new results show that ice readvanced during the Palivere stade and ceased during the Allerød chronozone. The age of this marginal zone has been tentatively correlated with that of the Levene zone in Sweden.

Acknowledgements. We would like to express our gratitude to L. Amon for identifying macrofossils and to the Elsevier language editing staff for linguistic help. We thank W. Wysota and two anonymous reviewers for their valuable comments and suggestions. The study was supported by the Estonian Ministry of Education and Research (projects SF0332710s06), the Estonian Research Council (SF0140021s12) and ESF (grant 8552).

\section{REFERENCES}

AMON L. and SAARSE L. (2010) - Postglacial palaeoenvironmental changes in the surrounding Lake Udriku in North Estonia. Geol. Quart., 54 (1): 85-94.

AMON L., VESKI S., HEINSALU A. and SAARSE L. (2012) - Timing of late-glacial vegetation dynamics and respective palaeoenvironmental conditions in southern Estonia: evidence from Lake Nakri sediment record. J. Quatern. Sc., 27: 169-180.

BERGLUND B. E. (1979) - The deglaciation of southern Sweden 13,500-10,000 B.P. Boreas, 8: 89-117.

BERGLUND B. E. and RALSKA-JASIEWICZOWA M. (1986) - Pollen analysis and pollen diagrams. In: Handbook of Holocene Palaeoecology and Palaeohydrology (ed. B. E. Berglund): 455-484. John Wiley and Sons, Chichester.

GRIMM E. (2007) - Tilia Version 1.0.1. Illinois State Museum. Reserch and Collection Center. Springfield.

HANG T., OJALA A., KOHV M. and TUVIKENE T. (2011) - Varve chronology and proglacial sedimentary environment in Pärnu area western Estonia. In: Late Pleistocene Glacigenic Deposits from the Central Part of the Scandinavian Ice Sheet to Younger Dryas End Moraine Zone. Excursion guide and Abstract (eds. P. Johansson, J. P. Lunkka and P. Sarala): 94-94: Geol. Surv. Finland, Rovaniemi.

HANG T. and SANDGREN P. (1996) - Magnetostratigraphy of varved clays. In: The Third Baltic Stratigraphic Conference. Abstracts. Field Guide (eds. T. Meidla, I. Puura, J. Nemliher, A. Raukas and L. Saarse): 152-154. Tartu.

HEIKKILÄ M., FONTANA S. L. and SEPPÄ H. (2009) - Rapid Lateglacial tree population dynamics and ecosystem changes in the eastern Baltic region. J. Quatern. Sc., 24: 802-815.
HEINSALU A. and VESKI S. (2007) - The history of the Yoldia Sea in Northern Estonia: palaeoenvironmental conditions and climatic oscillations. Geol. Quart., 51 (3): 295-306.

JOHNSEN T. F. (2010) - Late Quaternary ice sheet history and dynamics in central and southern Scandinavia. Dissertations from the Department of Physical Geography and Quaternary Geology, 22, Stockholm University, 1-32, http://su.diva-portal.org/smash/record.jsf?pid=diva2:311283

JOHNSEN T. F., ALEXANDERSON H., FABEL D. and FREEMAN S. P. H. T. (2009) - New ${ }^{10}$ Be cosmogenic ages from the Vimmerby Moraine confirm the timing of Scandinavian ice sheet deglaciation in southern Sweden. Geogr. Ann., 91A: 113-120.

JONES G. A. and HENRY G. H. R. (2003) - Primary plant succession on recently deglaciated terrain in the Canadian High Arctic. J. Biogeogr., 30: $277-296$.

KALM V. (2006) - Pleistocene chronostratigraphy in Estonia, southeastern sector of the Scandinavian glaciation. Quatern. Sc. Rev., 25: 960-975.

KALM V. (2011) - Ice-flow pattern and extent of the last Scandinavian Ice Sheet southeast of the Baltic Sea. Quatern. Sc. Rev. (published online 24.02.2011; DOI:10.1016/j.quacirev.2010.01.019)

KALM V., RAUKAS A., RATTAS M. and LASBERG K. (2011) - Pleistocene Glaciation in Estonia. In: Quaternary Glaciations - Extent and Chronology. A Closer Look (eds. J. Ehlers, P. L. Gibbard and P. D. Hughes): 95-104. Elsevier, Amsterdam.

KIHNO K., SAARSE L. and AMON L. (2011) - Late Glacial vegetation, sedimentation and ice recession chronology in the surroundings of Lake Prossa, central Estonia. Est. J. Earth Sc., 60: 147-158. 
LOKRANTZ H. and SOHLENIUS G. (2006) - Ice marginal fluctuations during the Weichselian glaciation in Fennoscandia, a literature review. Technical Report TR-06-36. Digitaltryck AB, Bromma, http://www.skb.se

LÕUGAS L., UKKONEN P. and JUNGNER H. (2002) - Dating the extinction of European mammoths: new evidence from Estonia. Quatern. Sc. Rev., 21: 1347-1354.

LOWE J. J., RASMUSSEN S. O., BJÖRCK S., HOEK W. Z., STEFFENSEN J. P., WALKER M. J. C., YU Z. C. and the INTIMATE group (2008) - Synchronisation of palaeoenvironmental events in the North Atlantic region during the Last Termination: a revised protocol recommended by the INTIMATE group. Quatern. Sc. Rev., 27: 6-17.

LUNDQVIST J. and WOHLFART B. (2001) - Timing and east-west correlation of south Swedish ice marginal lines during the Late Weichselian. Quatern. Sc. Rev., 20: 1127-1148.

LUNKKA J. P., JOHANSSON P., SAARNISTO M. and SALLASMAA O. (2004) - Glaciation of Finland. In: Quaternary Glaciations - Extent and Chronology. Part I: Europe (eds. J. Ehlers and P. L. Gibbard): 93-100. Elsevier, Amsterdam.

MANGERUD J., ANDERSEN S. T., BERGLUND B. E. and DONNER J. J. (1974) - Quaternary stratigraphy of Norden, a proposal for terminology and classification. Boreas, 3: 109-128.

PIRRUS R. (1969) - Stratigraphic division of South Estonian Late Glacial deposits by means of pollen analysis (in Russian with English summary). Eesti NSV Teaduste Akadeemia Toimetised, Keemia, Geoloogia, 18: 181-190.

PIRRUS R. and RAUKAS A. (1996) - Late-Glacial stratigraphy in Estonia. Proceed. Est. Acad. Sc., Geol., 45: 34-45.

PIRRUS R. and RÕUK A.-M. (1979) - New data on the geology of the Soitsj v Lake (in Estonian with English summary). In: Eesti NSV saark gustike ja j ven ude kujunemine (ed. A. Raukas): 118-144. Valgus, Tallinn.

RAUKAS A. (2004) - Application of OSL and ${ }^{10} \mathrm{Be}$ techniques to the establishment of deglaciation chronology in Estonia. Proc. Est. Acad. Sc., Geol., 53: 267-287.

RAUKAS A. (2009) - When and how did the continental ice retreat from Estonia. Quatern. Internat., 207: 50-57.

RAUKAS A. and STANKOWSKI W. (2005) - Influence of sedimentological composition on OSL dating of glaciofluvial deposits: examples from Estonia. Geol. Quart., 49 (4): 463-470.

RAUKAS A., RÄHNI E. and MIIDEL A. (1971) - Marginal glacial formations in North Estonia (in Russian with English summary). Valgus, Tallinn.

REIMER P. J., BAILLIE M. G. L., BARD E., BAYLISS A., BECK J. W., BERTRAND C., BLACKWELL P. G., BUCK C. E., BURR G., CUTLER K. B., DAMON P. E., EDWARDS R. L., FAIRBANKS R. G., FRIEDRICH M., GUILDERSON T. P., HUGHEN K. A., KROMER B., McCORMAC F. G., MANNING S., BRONK RAMSEY C., REIMER R. W., REMMELE S., SOUTHON J. R., STUIVER M., TALAMO S., TAYLOR F. W., van der PLICHT J. and WEYHENMEYER C. E. (2004) - IntCal04 terrestrial radiocarbon age calibration, 0-26 cal kyr BP. Radiocarbon, 46: 1029-1058.

RINTERKNECHT V. R., CLARK P. U., RAISBECK G. M., YIOU F., BROOK E. J., TSCHUDI S. and LUNKKA J. P. (2004) - Cosmogenic ${ }^{10} \mathrm{Be}$ dating of the Salpausselkä I Moraine in southwestern Finland. Quatern. Sc. Rev., 23: 2283-2289.

RINTERKNECHT V. R., CLARK P. U., RAISBECK G. M., YIOU F., BITINAS A., BROOK E. J., MARKS L., ZELČS V., LUNKKA J. P., PAVLOVSKAYA I. E., PIOTROWSKI J. A. and RAUKAS A. (2006) - The Last Deglaciation of the Southeastern Sector of the Scandinavian Ice Sheet. Science, 311: 1449-1452.

ROSENTAU A., HANG T. and KALM V. (2007) - Water-level changes and palaeogeography of proglacial lakes in eastern Estonia: synthesis of data from the Saadjärv Drumlin Field area. Est. J. Earth Sc., 56: 85-100.

ROSENTAU A., VASSILJEV J., HANG T., SAARSE L. and KALM V. (2009) - Development of the Baltic Ice Lake in the eastern Baltic. Quatern. Internat., 206: 16-23.
SAARNISTO M. and SAARINEN T. (2001) - Deglaciation chronology of the Scandinavian Ice Sheet from the Lake Onega Basin to the Salpaussekä End Moraines. Global Planet. Change, 31: 387-405.

SAARSE L. (1994) - Bottom deposits of small Estonian lakes (in Russian with English summary). Eesti Teaduste Akadeemia, Tallinn.

SAARSE L. (2011) - Timing of deglaciation in North Estonia. In: Late Pleistocene Glacigenic Deposits from the Central Part of the Scandinavian Ice Sheet to Younger Dryas End Moraine Zone. Excursion guide and Abstract (eds. P. Johansson, J. P. Lunkka and P. Sarala): 129-130. Geol. Surv. Finland, Rovaniemi.

SAARSE L., VASSILJEV J., ROSENTAU A. and MIIDEL A. (2007) - Reconstruction of Late Glacial shore displacement in Estonia. Baltica, 20: $35-45$.

SAARSE L., NIINEMETS E., AMON L., HEINSALU A., VESKI S. and SOHAR K. (2009) - Development of the late glacial Baltic basin and succession of the vegetation cover as revealed at Palaeolake Haljala, northern Estonia. Est. J. Earth Sc., 58: 317-333.

SEREBRYANNY L. R. and RAUKAS A. V. (1966) - Correlation of Gothiglacial ice marginal belts in the Baltic Sea depression and the neighbouring countries (in Russian with English summary). Baltica, 3: 235-250.

SOHAR K. and MEIDLA T. (2009) - The Late Glacial and Holocene environmental history of shallow lakes in Estonia, revealed from subfossil ostracod data. Geol. Quart., 53 (2): 209-218.

STANČIKAITĖ M., KABAILIENĖ M., OSTRAUSKAS T. and GUOBYTÉ R. (2002) - Environment and man around Lake Dăba and Pelesa, SE Lithuania, during the Late Glacial and Holocene. Geol. Quart., 46 (4): 391-409.

STANČIKAITÉ M., KISIELIENĖ D. and STRIMAITIENE் A. (2004) Vegetation response to the climatic and human impact changes during the Late Glacial and Holocene: case study of the marginal area of Baltija Upland, NE Lithuania. Baltica, 17: 17-33.

STANČIKAITE் M., ŠINKŪNAS P., ŠEIRIENĖ D. and KISIELIENĖ D. (2008) - Patterns and chronology of the Lateglacial environmental development at Pamerkiai and Kašučiai, Lithuania. Quatern. Sc. Rev., 27: $127-147$.

STOCKMARR J. (1971) - Tablets with spores used in absolute pollen analysis. Pollen et Spores, 13: 615-621.

STUIVER M., REIMER P. J. and REIMER R. (2005) - CALIB Radiocarbon Calibration (HTML Version 5.0), http://radiocarbon.pa.qub.ac.uk/calib/

SVENDSEN J. I., ALEXANDERSON H., ASTAKHOV V. I., DEMIDOV I., DOWDESWELL J. A., FUNDER S., GATAULLIN V., HENRIKSEN M., HJORT C., HOUMARK-NIELSEN M., HUBBERTEN H. W., INGÓLFSON Ó., JAKOBSSON M., KJÆR K. H., LARSEN E., LOKRANTZ H., LUNKKA J. P., LYSC A., MANGERUD J., MATIOUCHKOV A., MURRAY A., MÖLLER P., NIESSEN F., NIKOLSKAYA O., POLYAK L., SAARNISTO M., SIEGERT C., SIEGERT M. J., SPIELHAGEN R. F. and STEIN R. (2004) - Late Quaternary ice sheet history of Northern Eurasia. Quatern. Sc. Rev., 23: 1229-1271.

ZELČS V. and MARKOTS A. (2004) - Deglaciation history of Latvia. In: Quaternary Glaciations - Extent and Chronology. Part I: Europe (eds. J. Ehlers and P. L. Gibbard): 225-243. Elsevier, Amsterdam.

VASSILJEV J., SAARSE L. and MIIDEL A. (2005) - Simulation of the proglacial lake shore displacement in Estonia. Geol. Quart., 49 (3): 253-262.

VEBER K. (1969) - Das Moor Saku (in Estonian with German summary). Eesti Maaviljeluse ja Maaparanduse Teadusliku Uurimise instituudi Teaduslike tööde kogumik XVI: 248-274.

WARNER B. G., KUBIW H. J. and KARROW P. E. (1991) - Origin of postglacial kettle-fill sequence near Georgetown, Ontario. Can. J. Earth Sc., 28: 1965-1974.

WOHLFARTH B., BENNIKE O., BRUNNBERG L., DEMIDOV I., POSSNERT G. and VYAHIREV S. (1999) - AMS ${ }^{14} \mathrm{C}$ measurements and macrofossil analyses of a varved sequence near Pudozh, eastern Karelia, NW Russia. Boreas, 29: 575-586. 